\title{
DEVELOPING SOFTWARE ENGINEERING STUDENTS' READINESS FOR PROFESSIONAL MOBILITY THROUGH BLENDED LEARNING
}

\author{
Elvira Luzik, Oleksandra Akmaldinova, Larysa Tereminko
}

\author{
National Aviation University, Kyiv, Ukraine \\ luzik_nau@ukr.net, akmaldinova1304@ukr.net, tereminkolarisa@gmail.com
}

\begin{abstract}
The article aims to study the formation of the software engineering students' readiness for professional mobility in the educational and information environment of a technical university. The hypothesis of our research is the assumption that the formation of students' readiness for professional mobility depends on the following organisational and pedagogical conditions: 1) the development of students' positive intrinsic motivation for training and future professional activity using interactive methods and IT); 2) integration of the structure and content of foreign language with professional training by modelling professional activities through blended learning; 3) synergy of psychological and pedagogical process taking into account the components of the teacher's professional competence (a tutor, a moderator, a scientist, a designer, and a director). The pedagogical experiment was conducted at the National Aviation University and included three stages: preparatory, formative and final. In total, 158 students of I-V years of study majoring in software engineering took part in various stages of the experiment. 26 students made up an experimental group (EG), $24-$ a control group (CG). The criteria and indicators for assessing the students' readiness for professional mobility and the methods of evaluation were determined. The results of the experiment have proven the proposed hypothesis. The indicators of the productive and creative levels of readiness by all the criteria considerably increased in the EG, while in the CG a slight positive dynamics can be seen. Promising directions for further research can be related to the development of an integrative ESP Moodle course for future software engineers.
\end{abstract}

Keywords: readiness for professional mobility; future software engineer; interdisciplinary integration; ESP; blended learning.

\section{Introduction}

The creation of a single European labour market requires highly skilled professionals, obtaining not only theoretical knowledge but a high level of professional mobility. Forming key and special competences, critical thinking, dynamic abilities, motivation for education and self-improvement using blended learning technologies is becoming more widespread.

The research on forming readiness for professional mobility is stipulated by the rapid development of the software industry that results in the need to optimise and improve software engineers' professional training, which is currently not in line with the social and market needs. Graduate's competiveness is largely driven by professional mobility, which is one of the main traits of a successful specialist. Insufficient level of readiness for professional mobility impedes business activity and professional realisation. Due to the increased knowledge ageing, which occurs 2-3 times a year (several times a year and even more often in the field of IT), professional mobility is regarded as a means of continuous professional competence upgrading.

Thus, the problem of professional mobility is especially relevant for IT-specialists. Though a considerable number of people are employed in this area, competent professionals are always in demand. Higher requirements for hard and soft skills of job applicants, the need to solve complex professional problems and constantly master new software development methods result in high competition among software engineers and determine the specificity of training specialists of the field (Osadchyi \& Krasheninnik, 2017; Tereminko, 2017).

Our understanding of the notion "software engineers' professional mobility" is grounded on the analysis of their professional activity. Based on the sites of leading software development companies and the researched papers, we can conclude that the notion implies continuous adaptation to evolving working environments and technological development (Morozova \& Mendzebrovskyi, 2013). It requires perfect communication and teamwork skills for interaction with programmers, managers and customers having no technical background; a sound command of English to work in a multinational environment and learn new methods of developing software (Babii, 2013; Mignonac \& Herrbach, 2003); forming positive motivation for self-improvement and career advancement (França, Silva, Felix \& Carneiro, 2014, p. 79).

A number of scientific publications are devoted to academic (Beine, Noël \& Ragot, 2014; Dolga, Filipescu, Popescu-Mitroia \& Mazilescua, 2015), geographical (Iucu \& Pânişoară, 2011; Azoulay, Ganguli \& Zivin, 2017) and social (Marginson, 2018) mobility. A common practice is to implement longitudinal (Stumpf, 2014) and cross-cultural (Spence, Sturdy \& Carter, 2018) study approaches to mobility. The concept is primarily regarded as horizontal social and professional mobility correlating, to some extent, with integral personal characteristics.

Luzik, E., Akmaldinova, O., \& Tereminko, L. (2019). Developing software engineering students' readiness for professional mobility through blended learning. Advanced Education, 13, 103-111. DOI: 10.20535/2410-8286.185230 
Domestic mobility studies are characterised with a fairly clear separation of socio-economic, psychological and pedagogical approaches. They are aimed at forming mobility of specialists of different spheres with the focus on their personal (Sergeeva, 2015), psychological (Kerdyasheva, 2010) and motivational (Nedel'ko, 2007) readiness for professional mobility; comparing the international practice of investigating the issue (Sergeeva, 2015; Pavlenko, 2017; Semenog, 2016). Perhaps, the convergence and interpenetration of these currently uncorrelated approaches is a promising direction for domestic mobility studies.

Different aspects of the notion "readiness" are touched upon in scientific literature. The authors analyse relationship between the concepts "training" and "readiness" (Fedorenko, 2013), "readiness for professional activity" (Merkulova, 2008), "readiness for professional development" (Bartosiewicz et al., 2019) "commitment readiness" (Hadden et al., 2018), "occupational change readiness" (Otto et al., 2014) etc. The theses by Kerdyasheva (2010), Nedel'ko (2007) and Nikitina (2007) deal with the specificity of forming readiness for professional mobility while training specialists of different spheres.

The research on readiness for professional mobility in the educational and information environment of the technical university is related to the problems of intellectualisation of professional training (Mikhnenko, 2015); ensuring engineering mobility in the world (Rakhmanov, 2018); learning a foreign language as a means of forming professional mobility (Merkulova, 2008; Kerdyasheva, 2010; Chizhova, 2014). It is also grounded on the main regulations of the interdisciplinary approach (Luzik, 2010; Kaur \& Manan, 2013; Bodnar, 2016) and using innovative technologies of English for specific purposes (ESP) (Synekop, 2018) for integrating foreign language and professional training aimed at forming readiness for professional mobility.

In spite of the fact that the investigated concept is pervasive in domestic scientific studies, the theoretical and empirical research on readiness for professional mobility of software engineering students is still lacking. Based on the notion of "mobility" as the characteristic of human ability for constant change (Stumpf, 2014), we define "a software engineering student's readiness for professional mobility" concept as a complex, dynamic quality of an individual providing him/her with the ability to effectively adapt, perform and communicate for productive cooperation and promotion in a multinational environment, which demands flexible creative thinking for choosing nonstandard ways of solving problems by constantly learning and applying new methods of developing software, and improving professional skills (Tereminko, 2017). The notion combines various aspects of readiness: professional readiness (preparedness based on the level of a future specialist' competence) and psychological readiness - an energy condition mobilising an individual (the ability to respond quickly and predict one's own actions, make a right decision, adapt to working conditions, positively display acts of will). Both types of readiness are in dialectical unity and interact in the process of forming readiness for professional mobility (Fedorenko, 2013).

The aim of the article is to study the process of formation of the software engineering students' readiness for professional mobility in the educational and information environment of the technical university, whose components are: the social requirements of the labour market; software engineering standards; the graduate model formed in the content-oriented, organisational, estimative and monitoring synergic blocks to apply blended learning.

Since the synergic approach is realised in dominating self-education and self-organisation and implies the stimulating influence on the students aimed at their self-improvement in the process of cooperation with other people, we treat it as one of the conceptual approaches in our research. Its choice is also stipulated by the contradiction between orientation of academic disciplines on acquiring invariable knowledge and rapid technological development in IT that considerably outstrips the educational content and demands persistent skills of self-education, development of creative self-sufficiency; dominating of the rigid educational forms, which do not meet the students need in choosing the individual educational trajectory (Chupakhin, 2016).

The term "blended learning" implies the combination of distance and classroom instruction, in which the participants and organisers of the educational process cooperate both asynchronously and synchronously in time using, at the same time, educational technologies based on the principles of open education: largescale participation, accessibility, openness, comfort and interactivity (Boelens, Voet \& Wever, 2018).

The main tasks of the research are: 1) studying domestic and world experience of forming readiness for professional mobility of the future software engineers through the integration of their English and professional training (Tereminko, 2018); 2) defining its organisational and pedagogical conditions and technologies; 3) experimentally verifying the effectiveness of the educational and information environment of this process.

The hypothesis of our research is the assumption that the formation of readiness for professional mobility depends on the following organisational and pedagogical conditions: 1) the purposeful development of students' positive intrinsic motivation for training and future professional activity using interactive methods and information technologies (IT); 2) integration of the structure and content of foreign language 
with professional training by modelling specialists' professional activities through blended learning; 3) synergy of psychological and pedagogical process of forming readiness for professional mobility of the future software engineers, which is specified by taking into account the components of the teacher's professional competence (a tutor, a moderator, a scientist, a designer, and a director).

The conceptual feature of the study conducted is introducing blended learning into the integrated educational process combining the future software engineers' foreign language and professional training that influenced the structure and the content of the academic disciplines "Foreign Language" and "ESP". The educational and information environment was built on the combination of the authors' course "Professional English. Fundamentals of Software Engineering" (Akmaldinova et al., 2015) designed for class work and the on-line course "English for the Workplace" (British Council, 2019) intended for distance training.

\section{Methods}

The pedagogical experiment included three stages: preparatory, formative and final. The Department of Software Engineering, the Department of Foreign Languages for Specific Purposes and the Department of Pedagogy and Psychology of Professional Education of the National Aviation University were chosen to carry out an experimental study. In total, 158 students of I-V years of study majoring in software engineering took part in various stages of the experiment. We have implemented such ethical principles in our research as students' voluntary participation; informed consent (participants were fully informed about the procedures of research and gave their consent to participate; confidentiality (research information was not available to anyone who was not directly involved in the study); anonymity and confidentiality.

At the preparatory stage, based on the system and synergic approaches, the conceptual apparatus of the study was formed, the experimental programme was developed, and the ascertaining experiment was conducted. We also chose diagnostic methods and psychological tests for studying students' individual psychological characteristics, raising their psychological awareness and creating conditions for successful learning, determining the results of ascertaining and formative experiments. At this stage, general scientific and specific scientific methods (interdisciplinary, structural scientific and system and functional analyses, comparison, classifications) were used to determine the conceptual grounds of the research, substantiating the appropriateness of the organisational and pedagogical conditions and developing the educational technologies of forming the future software engineers' readiness for professional mobility; empirical methods (diagnostics, observation, questionnaires, surveys) to evaluate the input level of readiness for professional mobility.

To check the effectiveness of implementing the organisational and pedagogical conditions, the components of readiness for professional mobility of the specified specialists were distinguished: personality, motivational, cognitive, technological and reflexive (Tereminko, 2018). The personality component characterises the ability to adapt in the educational and professional environment according to professional, social and personal needs. The motivational component includes the system of motives and goals, the need for self-development, self-improvement and self-education, the attitude for self-actualisation in the professional activity. The cognitive component integrates theoretical knowledge, practical experience with the process of cognition. The technological component is an integrative competence that allows successful interpersonal communication, application of information and communication technologies (ICTs) to facilitate performing personal and professional tasks. The reflexive component represents the ability to evaluate one's own motives, interests, value orientations and the readiness to apply ICTs.

To assess the quality of the pedagogical experiment, the criteria for evaluating the students' readiness for professional mobility, which coincide with the names of the above mentioned structural components (Table 1), were identified (Tereminko, 2018).

Table 1. Criteria and indicators for assessing software engineering students' readiness for professional mobility

\begin{tabular}{|c|c|}
\hline Criterion & Indicators \\
\hline personality & $\begin{array}{l}\text { - adaptively important traits: high activity, ability to work, emotional stability, } \\
\text { responsibility, independence, goal orientation and initiative; } \\
\text { - developed communicative and interpersonal skills; }\end{array}$ \\
\hline motivational & $\begin{array}{l}\text { - stable interest to professional activity; } \\
\text { - awareness of the necessity to develop professionally; } \\
\text { - the need for developing professionally important qualities in the field of ICTs, } \\
\text { constant self-development, self-education and self-improvement; }\end{array}$ \\
\hline
\end{tabular}




\begin{tabular}{|l|l|}
\hline cognitive & - the knowledge on readiness for professional mobility and one's own individual and \\
psychological characteristics; \\
$-\quad$ technological skills and recognition of software engineering prospects; \\
- creativity in solving educational and professional tasks;
\end{tabular}

In order to check the formation of components of readiness for professional mobility, the methods of their evaluation according to the specified criteria were used. The personal criterion: the multi-factor Cattell 16PF questionnaire (Lemak \& Petryshche, 2012) and the adaptability test by Rogers (Kominko \& Kucher, 2005). The motivational criterion: "Motivation of Studying at the Higher Educational Institution" questionnaire by Illina (Turishcheva, 2009), the questionnaire to study the motivation of success and attitude to academic subjects by Kazantseva and "Psychological Readiness for Professional Activity" test by Kabardova (Lemak \& Petryshche, 2012). The cognitive criterion: "Freedom of Association" questionnaire by Zivert (Turishcheva, 2009) and the creativity test by Torrance (Kominko \& Kucher, 2005). The technological criterion: sociometry to check the team work skills (Turishcheva, 2009); evaluating the skills of searching and managing information; applying ICTs in the process of training and self-education; making presentations; communication with native speakers; module and complex tests (checking the level of the English competence in reading, writing, speaking, listening and translating). I-II terms: "Autonomy of students" questionnaire by Petrovskaya (Kominko \& Kucher, 2005) to determine the students' learning strategies; taking part in brainstorming, role plays, discussions and Olympiads; III-IV terms: unsupervised work on learning new methods and technologies of developing software, programming languages, technical literature on specialty in English; technical and technological awareness; taking part in interdisciplinary conferences, project and creative tasks, case-studies. The reflexive criterion: diagnostics of the level of reflexivity (questionnaire by Karpov) (Lemak \& Petryshche, 2012), filling in self-evaluation cards by the students and assessing them by the teachers; surveys and observations.

The purpose of the formative experiment was to implement the organisational and pedagogical conditions of the study while teaching English and ESP to 26 students majoring in software engineering in IVI terms at the tertiary level. The formative stage of the experiment took place in the real teaching process using blended learning. 26 students made up an experimental group (EG), 24 - a control group (CG). The same syllabi were used to teach both groups, but the organisational and pedagogical conditions formed in our study were applied only to the experimental group.

To realise the first organisational and pedagogical condition, such interactive methods and motivational tasks were used: role-playing and situational games, discussions, disputes, interviews, brainstorming, writing essays and annotations of the English tests. The topics of interest were: "Professional Mobility in Software Engineering", "English in the Career of IT-Specialist", "Software Engineer Professional Development", "Wellknown Programmers" (I-II terms); "Modern Programming Languages", "Learning English: My Experience", "Innovations in IT", "Secret Functions of Modern Gadgets", "New Network Technologies", "Cloud Computing" (III-IV terms); "Leading Software Companies", "Communication Strategies", "Rules of Successful Interview", "Ukrainian Women in Programming", "Artificial Intelligence Concerns" (V-VI terms).

Blended learning became the means of realising the second and the third organisational and pedagogical conditions through combining the above-mentioned course "Professional English. Fundamentals 
of Software Engineering" (Akmaldinova et al., 2015) (I-IV terms) and the massive open online course "English for the Workplace" (British Council, 2019) on the social learning platform FutureLearn (V-VI terms). The textbook "Professional English. Fundamentals of Software Engineering" (Akmaldinova et al., 2015) consists of 12 units revealing the following professionally oriented subject matter: computer hardware, operating systems, human machine interface, software construction and software modelling (I-II terms, English); software architecture and software design, databases, multimedia, information systems, computer security, software and data security (III-IV terms, ESP). Each unit contains authentic professionally oriented texts, accompanied by the English-Ukrainian professional vocabulary and a complex of lexico-grammatical and communicative exercises aimed at consolidating and monitoring the students' progress, which facilitates their future professional, engineering and scientific activities in a globalised world. Class and individual work with the textbook immersed in the context of future professional activities and contributed to the development of the positive intrinsic motivation in obtaining foreign language professional competence. Mastering ESP ensured the improvement of the students' mental processes approaching a high level of adaptability to social and professional displacement. Cognitive and research tasks developed the intelligence and professional outlook, necessary to find the way out of problem situations; taught the art of interpersonal relationships, the techniques of personal and professional communication (Tereminko, 2018).

The online course "English for the Workplace" (British Council, 2019) (V-VI terms, ESP) consists of four modules that are useful for developing the skills of professional and business communication, selfpresentation, job hunting, employment and team work. The course topics (plans for the future; job hunting; job advertisements; writing a CV and a cover letter; interviewing; skills and experience; job responsibilities; working rules and company management; working day and relationships with colleagues; rules of the team work; planning, solving and discussing tasks; business communication) are relevant both for students attending different professional courses and interviews, getting their first working experience, and for those who plan such an experience in future.

The most effective forms of work during the formative experiment were self-presentations and presentations of individual and group projects, business meetings, using interactive and ICT technologies; students' scientific clubs, conferences and Olympiads, contests of scientific projects. To form associative competence links of readiness for professional mobility and the ability to make responsible decisions in uncertain conditions, speak-up and discussion clubs, role-playing and situational games, case-studies and meetings with stakeholders were used.

After conducting the formative experiment, we used the empirical methods (diagnostic tests and questionnaires mentioned above, observation and surveys etc.) to evaluate the level of readiness for professional mobility of the future software engineers, namely: reproductive - basic expression of indicators of readiness for professional mobility; productive - situational expression of the indicators; creative - high indicators by all the criteria of readiness for professional mobility realised in the creative approach and the ability to quickly find, analyse and apply information, effectively change the types and forms of educational and professional activities (Frolov, 2004). At the final stage, the results of the EG and CG were generalised and compared using Pearson's $\chi^{2}$-criterion.

\section{Results}

The results of the conducted experiment have proven a positive change in the indicators by all the criteria, for example, of the motivational component of forming readiness for professional mobility: the number of students in the EG having the reproductive level of this component decreased from $30.8 \%$ to $15.4 \%$ (in CG - from $33.3 \%$ to $25 \%$ ); while the number of students having demonstrated the productive level increased from $46.1 \%$ to $53.8 \%$ (in CG - from 37,5 to $41.7 \%$ ); the number of students having the creative level increased from $23.1 \%$ to $30.8 \%$ (in CG - from $29.2 \%$ to $33.3 \%$ ). Positive dynamics at the creative level was observed in all the other criteria, namely: personality (the growth in the EG was 19.2\% and in the CG $-8.3 \%)$, cognitive $(19.2 \%$ and $4.2 \%$ respectively), technological (the growth in the EG was $11.5 \%$ and in the $\mathrm{CG}-4.1 \%)$ and reflexive (15.3\% and $12.5 \%$, respectively).

The analysis of the results of the experiment (Table 2) shows the effectiveness of the realisation of the organisational and pedagogical conditions of readiness for professional mobility of the future software engineers in the process of integration of their foreign language and professional training through blended learning. The indicators of the productive and creative levels of readiness for professional mobility considerably increased in the EG, while in the CG a slight positive dynamics can be seen. Significant differences between the groups constitute the value of $p \leq 0.05$. 
Table 2. Levels of readiness for professional mobility before and after the formative experiment, $\%$

\begin{tabular}{|c|c|c|c|c|c|c|c|}
\hline \multirow{3}{*}{$\begin{array}{l}\text { Components of } \\
\text { readiness for } \\
\text { professional } \\
\text { mobility }\end{array}$} & \multirow{3}{*}{$\begin{array}{c}\text { Groups } \\
\text { (number } \\
\text { of } \\
\text { students) }\end{array}$} & \multicolumn{6}{|c|}{ Levels, $\%$} \\
\hline & & \multicolumn{2}{|c|}{ Reproductive } & \multicolumn{2}{|c|}{ Productive } & \multicolumn{2}{|c|}{ Creative } \\
\hline & & before & after & before & after & before & after \\
\hline \multirow[t]{2}{*}{ Personality } & EG (26) & $46,1(12)$ & $26,9(7)$ & $34,6(9)$ & $34,6(9)$ & $19,2(5)$ & $38,4(10)$ \\
\hline & CG (24) & $54,1(13)$ & $41,7(10)$ & $29,2(7)$ & $33,3(8)$ & $16,7(4)$ & $25,0(6)$ \\
\hline \multirow[t]{2}{*}{ Motivational } & EG (26) & $30,8(8)$ & $15,4(4)$ & $46,1(12)$ & $53,8(14)$ & $23,1(6)$ & $30,8(8)$ \\
\hline & CG (24) & $33,3(8)$ & $25,0(6)$ & $37,5(9)$ & $41,7(10)$ & $29,2(7)$ & $33,3(8)$ \\
\hline \multirow[t]{2}{*}{ Cognitive } & EG (26) & $26,9(7)$ & $30,8(8)$ & $53,8(14)$ & $30,8(8)$ & $19,2(5)$ & $38,4(10)$ \\
\hline & CG (24) & $33,3(8)$ & $25,0(6)$ & $45,8(11)$ & $50,0(12)$ & $20,8(5)$ & $25,0(6)$ \\
\hline \multirow[t]{2}{*}{ Technological } & EG (26) & $46,1(12)$ & $30,8(8)$ & $26,9(7)$ & $30,8(8)$ & $26,9(7)$ & $38,4(10)$ \\
\hline & CG (24) & $37,5(9)$ & $33,3(8)$ & $33,3(8)$ & $33,3(8)$ & $29,2(7)$ & $33,3(8)$ \\
\hline \multirow[t]{2}{*}{ Reflexive } & EG (26) & $38,4(10)$ & $26,9(7)$ & $30,8(8)$ & $26,9(7)$ & $30,8(8)$ & $46,1(12)$ \\
\hline & CG (24) & $41,7(10)$ & $37,5(9)$ & $37,5(9)$ & $29,2(7)$ & $20,8(5)$ & $33,3(8)$ \\
\hline
\end{tabular}

\section{Discussion}

Thus, the obtained results have proven the proposed hypothesis. The important conclusion, based on the results, supplementing the findings by França, Silva, Felix \& Carneiro (2014) is that the development the of students' positive intrinsic motivation for training and future professional activity is facilitated by the actualisation of professional goals, values and personal needs; individual and differentiated approaches; integrative training materials, which appeal to the students' experience; using such motives, as professional interest, creative educational activity, competitiveness, educational games, emotional impact and all-round support of any inner students' aspirations; teaching the self-motivation techniques.

At the same time, in our research, we effectively used the didactic potential of foreign language instruction in the formation of readiness for professional mobility, which is consistent with Merkulova (2008), Chizhova (2014) and Kerdyashova (2010). The integration of the two main types of educational activities in the process of foreign language training - cognition and communication - improved memory, attention, imagination, intelligence and analytical thinking enabling the development of adaptation, socialisation, skills of solving nonstandard problems, necessary for professional mobility of a future specialist. In addition, individualisation and differentiation, optimising the purpose, content, methods and forms of the educational process, the use of special methodological support aimed at intensifying language instruction and the application of innovative technologies are effective ways of forming readiness for professional mobility (Tereminko, 2018).

The communicative function of a foreign language facilitated mastering professional disciplines, since context-based language acquisition provided for the improvement of mental processes, approaching a high level of adaptability to the specifics of the professional sphere (Bodnar, 2016). Learning a foreign language (listening, speaking, reading and writing) at the intercultural and professional levels enhanced the formation of communicative (the ability to cooperate with other people in a foreign language environment), motivational-value (professional orientation), personality-activity (the ability to analyse, synthesise and plan; devotion to one's company, tolerance, diligence and team working skills) and reflexive (the ability to selfeducation, self-analysis and self-realisation) components of readiness for professional mobility.

Given that the foreign language as a discipline is "objectless", it is easily integrated with other disciplines filling it with thoughts and laws of the objective reality being the subject of their study. Integration of foreign language and professional training made it possible to immerse the future specialists in the context of their professional activities. Interdisciplinary links helped students learn a foreign language in a quasi-professional educational environment. This enhanced cognitive and practical skills, formed a personal attitude to a particular professional activity, caused emotional satisfaction with the educational activity, as well as stimulated the desire to master creative methods of labour activity (Merkulova, 2008).

The versatility and variability of the content of the disciplines "Foreign Language" and "ESP", the opportunity of the teacher to choose certain forms, methods and means were undoubtedly important for the formation of communicative, motivational-value, cognitive, personality-activity and reflexive components of readiness for professional mobility in our research. We could actualise certain aspects of reality associated with readiness for professional mobility, familiarise students with the prevalent life values, world mobility processes; enabled increasing the motivation to studying by taking into account the individual characteristics and interests of young people and facilitated the development of personal and professional qualities. Using proper forms, methods and means of teaching a foreign language brought students closer to the situation of 
professional reality by mastering samples of constructive professional behaviour and lifestyle and thereby formed readiness for professional mobility (Kerdyashova, 2010).

Our study suggests that one of the means of optimising the formation of readiness for professional mobility of a future software engineer in the process of foreign language instruction is blended learning, which implements the transition from a traditional model of education to an integrated one using electronic resources (Boelens, Voet \& Wever, 2018). Let us prove it.

As a result of our own observations and surveys, on the third year of studying students are trying to find a job and start working, given a high salary in software engineering, which is the biggest motivating factor. Labour activities in the student's age foster the formation of practical skills in the professional area, rapid career advancement and the development of all components of professional mobility (Voronovs'ka, 2015). The application of the training courses "Professional English. Fundamentals of Software Engineering" (Akmaldinova et al., 2015) and "English for the Workplace" (British Council, 2019) through blended learning, combining the class and the distant work, helped develop self-education and self-development skills, as well as the ones of searching and selecting information, performing creative tasks, forming the skills of making and presenting projects; developed responsibility. Flexibility of e-learning and access to educational material at any time and place provided students with the advantage in learning and the opportunity to catch up on their lessons. Using electronic resources and more interesting forms of work (web quests, games, online conferences and webinars, audio and video materials, forums, blogs, PowerPoint slides etc.) brought diversity into the educational process and increased the students' motivation, formed the skills of planning and organising their own activities. Students with a higher level of English could choose more complex tasks, thereby implementing the differentiation of education, which considers their individual perception peculiarities (Mikhnenko, 2015; Bihych \& Okopna 2018; Synekop, 2018). In addition, changing the role of the teacher, who acted as a mentor, a coordinator, a moderator, a tutor and a scholar in the proper educational situations contributed to improving the quality of his communication with students providing feedback and qualitative assessment, and giving students the opportunity to receive recommendations as to enhancing their learning activities.

\section{Conclusions}

Transition from the knowledge paradigm to the productive thinking one in the system of professional training of future software engineers requires the innovative educational and information environment that would form a specialist possessing critical thinking, able to function effectively in a synergic professional environment (Luzik \& Khomenko-Semenova, 2018). Therefore, the formation of readiness for professional mobility of a future software engineer in the process of blended integrated foreign language and professional training should form such an open dynamic synergetic educational environment, whose structure and content will shift the focus from transmission of knowledge to the process of acquiring it from the open information environment using projects and problem situations instead of traditional classes.

The prospects of further research, as we can see them, are in the development of an integrative educational ESP Moodle course for future software engineers and a more detailed consideration of the mechanism of implementing operational, prognostic, strategic and conceptual feedback in interdisciplinary integration. It can be also mentioned that there is a lack of research on using blended learning to form readiness for professional mobility.

\section{References}

Akmaldinova, O. M., Buhaiov, O. Ye., Tereminko, L. H., Hurs'ka, O. O., Myslyva, T. A. \& Murkina, N. I. (2015). Professional English. Fundamentals of Software Engineering. Kyiv: NAU

Azoulay, P., Ganguli, I. \& Zivin, J. (2017). The mobility of elite life scientists: Professional and personal determinants. Research Policy, 46(3), 573-590. https://doi.org/10.1016/j.respol.2017.01.002

Bartosiewicz, A., Łuszczki, E., Różański, A. \& Nagórska, M. (2019). Analysis of Determinants of Readiness for Professional Development Among Polish Nurses. International Journal of Environmental Research and Public Health, 16(10), 34-46. https//:doi.org/10.3390/ijerph16101800

Babii, H. V. (2013). Analiz vymoh do osobystisnykh ta profesinykh yakostei inzheneriv iz prohramnoho zabezpechennia v konteksti fomuvannia hotovnosti do profesiinoho spilkuvannia [Analysis of the requirements for software engineer personal and professional skills in the context of professional communication readiness development]. Science and Education a New Dimension: Pedagogy and Psychology, 7, 17-22. Retrieved 18.11.2019 http://seanewdim.com/uploads/3/4/5/1/34511564/ seanewdim2013vol7pedpsych.pdf

Beine, M., Noël R. \& Ragot, L. (2014). Determinants of the international mobility of students. Economics of Education Review, 41, 40-54. https://doi.org/10.1016/j.econedurev.2014.03.003

Bihych, O. \& Okopna Ya. (2018). E-learning in professionally oriented German communicative competence formation of students majoring in tourism management. Advanced Education, 9, 126-131. http://doi.org/10.20535/2410-8286.132499

Bodnar, S. (2016). Content and language integrated teaching to Ukrainian university students majoring in economics. Advanced Education, 6, 53-59. http://doi.org/10.20535/2410-8286.73872 
Boelens, R., Voet, M. \& Wever B. (2018). The design of blended learning in response to student diversity in higher education: Instructors' views and use of differentiated instruction in blended learning. Computers \& Education, 120, $197-212$. https://doi.org/10.1016/j.compedu.2018.02.009

British Counci (2019). English for the workplace. Retrieved 10.11.2019 https://www.futurelearn.com/courses/workplace-english

Chizhova, N. V. (2014). Rol' inozemnoi movy u formuvanni profesiinoi mobil'nosti maibutnikh fakhivtsiv z reklamy [The Role of Foreign Language in Formation of Future Advertising Experts' Professional Mobility]. Advanced Education, 1, 76-82. https://doi.org/10.20535/2410-8286.29478

Chupakhin, S. A. (2016). Zastosuvannia systemno-synerhetychnoho ta kontekstnoho pidhodiv pry formuvanni profesiinoi kompetentnosti u maibutnikh inzheneriv-zviazkivtsiv [Application of System-Synergetic and Contextual Approaches for the Formation of Professional Competence of Future Engineers-Signalmen]. Virtus, 8, 121-124. Retrieved 05.11.2019 http://dspace.tneu.edu.ua/jspui/bitstream/316497/11297/1/Journal8.pdf

Dolga, L., Filipescu, H., Popescu-Mitroia, M. M. \& Mazilescua, C. A. (2015). Erasmus mobility impact on professional training and personal development of students beneficiaries. Procedia - Social and Behavioral Sciences, 191, 1006-1013. https//:doi.org/10.1016/j.sbspro.2015.04.235

Fedorenko, O. I. (2013). Do zmistu poniat" "pidhotovka" ta "hotovnist"' do profesiinoi diial'nosti maibutnikh pravookhorontsiv [The Content of Concepts "Training" and "Readiness" for Professional Activity of Future Employees of the Law Enforcement Sphere]. Dukhovnist' osobystosti: metodolohiya, teoriya $i$ praktyka, 57(4),190-198. Retrieved 15.11.2019 http://nbuv.gov.ua/UJRN/domtp_2013_4_24

França A., Silva F., Felix A. \& Carneiro D. (2014). Motivation in software engineering industrial practice: A cross-case analysis of two software organisations. Information and Software Technology, 56(1), 79-101. https://doi.org/10.1016/j.infsof.2013.06.006

Frolov, Yu. V. \& Makhotyn, D. A. (2004). Kompetentnostnaya model' kak osnova otsenki kachestva podgotovki specialistov [Competence Model as a Basis for Assessing the Quality of Training the Specialists]. Vysshee obrazovanie segodnya, 8, 34-41.

Hadden, B. W., Agnew, C. R. \& Tan, K. (2018). Commitment Readiness and Relationship Formation. Personality and Social Psychology Bulletin, 44(8), 1242-1257. https://doi.org/10.1177/0146167218764668

Iucu, R., Pânişoară, I. \& Pânişoară, G. (2011). The professional mobility of teachers - new tendencies in the global society. Procedia - Social and Behavioral Sciences, 11, 251-255. https//:doi.org/10.1016/j.sbspro.2011.01.071

Kaur, S. \& Manan, S. A. (2013). Developing interdisciplinary teaching: a vignette of a postgraduate course. Procedia - Social and Behavioral Sciences, 90, 755-763. https//:doi.org/10.1016/j.sbspro.2013.07.149

Kerdyasheva O. V. (2010). Pedagogicheskiye usloviya formirovaniya gotovnosti $k$ professional'noi mobil'nosti studentov $v$ obrazovatel'nom protsesse vuza [Pedagogical Conditions of Forming Readiness for Professional Mobility of Students in the Educational University Process]. Unpublished candidate dissertation, Voronezh, Russia.

Kominko, S. B. \& Kucher H. V. (2005). Krashchi metody psychodiahnostyky [The Best Methods of Psychological Diagnosis]. Ternopil': Kart-blansh.

Lemak, M. V. \& Petryshche, V. Yu. (2012). Psykholohu dlia roboty. Diahnostychni metodyky [Guidance for Psychologist's Work. Diagnostic Methods]. Uzhhorod: Vydavnytstvo Oleksandry Harkushi.

Luzik, E. V. (2010). Intehratyvnyi navchal'nyi kurs yak teoretyko-metodolohichna osnova profesiynoho stanovlennia tvorchoi osobystosti fakhivtsia v systemi vyshchoi tekhnichnoi osvity [Integrated Learning Course as Theoretical and Methodological Basis for the Formation of Professional Creative Personality of a Specialist in the System of Higher Technical Education]. Visnyk Natsional'noho aviatsiynoho universytetu, 3, 4-12. https//:doi.org/10.18372/2411264X.3.2142

Luzik, E. \& Khomenko-Semenova, L. (2018). Innovatsiynist' rozvytku vyshchoi technichnoi osvity v Ukraini yak osnova formuvannia planetarnoho myslennia maybutnioho fakhivtsia. [Innovation of Higher Educational Development in Ukraine as the Basis of Forming the Planetary Thinking of the Future Specialist]. Visnyk Natsional'noho aviatsiynoho universytetu, 12, 74-81. https://doi.org/10.18372/2411-264X.12.12905

Marginson, S. (2018). Higher education, economic inequality and social mobility: Implications for emerging East Asia. International Journal of Educational Development, 63, 4-11. https://doi.org/10.1016/j.ijedudev.2017.03.002

Merkulova, L. P. (2008). Formirovaniye professional'noy mobil'nosti spetsialistov tekhnicheskogo profilya sredstvami inostrannogo yazyka [The Formation of Professional Mobility of Technical Specialists by Means of a Foreign Language]. Unpublished doctoral dissertation, Samara, Russia.

Mignonac, K. \& Herrbach, O. (2003). Managing individual career aspirations and corporate needs: a study of software engineers in France. Journal of Engineering and Technology Management, 20(3), 205-230. https://doi.org/10.1016/S09234748(03)00019-5

Mikhnenko, G. E. (2015). Treating the concept "intellectual mobility" as an integrated characteristic of future professionals. The Advanced Science Journal, 1, 71-74. http://doi.org/10.15550/asj.2015.01.071

Morozova T. Yu. \& Mendzebrovs'kyi I. B. (2013). Novyi instrument informatsiinoho obminu mizh rynkom pratsi ta IT-osvitoiu. [New Insrument of Labour Market and IT-Education Interchange]. Software Engineering, 1(13), 34-39.

Nedel'ko, Ye. G. (2007). Formirovaniye motivatsionnoy gotovnosti k professional'noy mobil'nosti u studentov vuza [Forming Readiness for Professional Mobility of the University Students]. Unpublished candidate dissertation, Magnitogorsk, Russia.

Nikitina,Ye. A. (2007). Pedagogicheskiye usloviya formirovaniya professional'noy mobil'nosti budushchego pedagoga [Pedagogical Conditions of Forming Professional Mobility of Future Teachers]. Unpublished candidate dissertation, Moscow, Russia.

Osadchyi, V. V. \& Krasheninnik, I. V. (2017). Formuvannia zmistu osvitnikh program pidhotovky maibutnikh inzhenerivprogramistiv za skorochenym terminom navchannia na osnovi analizu rynku pratsi [Forming the content of educational programmes of future software engineers' short-time training based on the labour market study]. Informatsiini tekhnolohiyi i zasoby navchannia, 58(2), 11-25. Retrieved 06.11.2018 http://nbuv.gov.ua/UJRN/ITZN_2017_58_2_4 
Otto, K., Dette-Hagenmeyer, D. \& Dalbert, C. (2014). Occupational change readiness at career transition points in those at the beginning of their working life. Journal Psychologie des Alltagshandelns / Psychology of Everyday Activity, 7 (1), 19-29. Retrieved 10.11.201 https://www.researchgate.net/publication/268149660_Occupational_change_readiness_at_career_ transition_points_in_those_at_the_beginning_of_their_working_life

Pavlenko, M. (2017). The problem of developing professional mobility of teachers in the works of foreign scholars. Comparative Professional Pedagogy, 7(4), 132-138. https//:doi.org/10.1515/rpp-2017-0061

Rakhmanov, V. O. (2018). Teoretychni i metodychni zasady pidhotovky maibutnikh inzheneriv v umovakh osvitnio-informatsiinoho seredovyshcha tekhnichnoho universytetu: monohrafiya [Theoretical and Methodical Principles of Training Future Engineers in the Conditions of the Educational and Information Environment of the Technical University]. Kyiv, Ukraine: TSP Komprynt.

Semenog, O. (2016). Forming professional mobility in the process of future master filologists' training in Ukraine and abroad. Comparative Professional Pedagogy, 6(4), 27-33. https//:doi.org/10.1515/rpp-2016-0044

Sergeeva, T. B. (2015). Personal and professional mobility: the conjugacy problem. Science and Education, 127(8), 81-96. https//:doi.org/10.17853/1994-5639-2015-7-81-96

Spence, C., Sturdy, A. \& Carter, C. (2018). Professionals with borders: The relationship between mobility and transnationalism in global firms. Geoforum, 91, 235-244. https://doi.org/10.1016/j.geoforum.2018.03.012

Stumpf, S. A. (2014). A longitudinal study of career success, embeddedness, and mobility of early career professional. Journal of Vocational Behavior, (85)2, 180-190. https://doi.org/10.1016/j.jvb.2014.06.002

Synekop, O. (2018). Cognitive aspect of learning style in differentiated ESP instruction for the future IT specialists. Advanced Education, 10, 40-47. http://doi.org/10.20535/2410-8286.151271

Tereminko, L. H. (2017). Formuvannia hotovnosti do profesiinoi mobil'nosti yak aktual'na problema profesiinoi pidhotovky maibutnikh fakhivtsiv z inzhenerii prohramnoho zabezpechennia. [Formation of Readiness for Professional Mobility as an Urgent Professional Training Problem of Future Software Engineers]. Visnyk Natsional'noho aviatsiynoho universytetu, 10, 139-145. https:// doi.org/10.18372/2411-264X.10.12521

Tereminko, L. H. (2018). Model' formuvannia hotovnosti do profesiinoi mobil'nosti maibutnikh fakhivtsiv z inzhenerii prohramnoho zabezpechennia u protsesi inshomovnoyi pidhotovky [Forming Readiness for Professional Mobility of Future Software Engineers in the Process of Foreign Language Training]. Innovatsiina pedahohika, 8, 159-163.

Tereminko, L. H. (2018). Sotsial'no-osobystisna ta profesiino-tekhnichna spriamovanis't inshomovnoi pidhhotovky yak chynnyk formuvannia hotovnosti do profesiinoi mobil'nosti maibutnikh fakhivtsiv z inzhenerii prohramnoho zabezpechennia. [Socially Personal and Professionally Oriented Foreign Language Training as a Factor of Forming Readiness for Professional Mobility of Future Software Engineers]. Science and Education a New Dimension. Humanities and Social Sciences, 184, 61-64. https://doi.org/10.31174/SEND-HS2018-184VI30-15

Turishcheva, L. V. (2009). Nastil'na knyha practychnoho psyholoha [Handbook for a Practicing Psychologist]. Kharkiv: Osnova

Voronovs'ka, L. P. (2015). Pedahohichni umovy formuvannia profesiinoi mobil'nosti maibutnikh fakhivtsiv komunal'noho hospodarstva. [Pedagogical Conditions of Professional Mobility of Future Municipal Services Specialists]. Pedahohika ta psykhologiia, (51), 143-150. http://doi.org/10.5281/zenodo.34175 